\title{
Silicon Corrosion in Neutral Media: The Influence of Confined Geometries and Crevice Corrosion in Simulated Physiological Solutions
}

\author{
Emilija Ilic, ${ }^{1,2, z}$ Ainhoa Pardo, ${ }^{1}$ Roland Hauert, ${ }^{1}$ Patrik Schmutz, ${ }^{1, *}$ and Stefano Mischler ${ }^{2, *}$ \\ ${ }^{I}$ Empa, Swiss Federal Laboratories for Materials Science and Technology, Laboratory for Joining Technologies and \\ Corrosion, Switzerland \\ ${ }^{2}$ EPFL, Ecole Polytechnique Fédérale de Lausanne, Tribology and Interfacial Chemistry Group, Lausanne, Switzerland
}

\begin{abstract}
Silicon ( $\mathrm{Si}$ ) based implantable components are widely used to restore functionalities in the human body. However, there have been reported instances of Si corroding after only a few years of implantation. A key parameter often overlooked when assessing Si stability in-vitro, is the added constricting geometries introduced through in-vivo implantation. The influence of crevices and confined solutions on the stability of $\mathrm{Si}$ is presented in this study, considering two simulated physiological solutions: $0.01 \mathrm{M}$ phosphate buffered saline (PBS) and HyClone Wear Test Fluid (WTF). It was found that Si is highly vulnerable to corrosion in confined/crevice conditions. High pitting corrosion susceptibility is found in a crevice, whereas a dissolution rate of ca. $3.6 \mathrm{~nm} / \mathrm{h}$ at body temperature occurred due to local alkalization within a confined cathodic area. The corrosion rates could be increased by elevating the temperature and yielded linear Arrhenius relations, with activation energies of $106 \mathrm{KJ} / \mathrm{mol}$ in $0.01 \mathrm{M} \mathrm{PBS}$ and $109 \mathrm{KJ} / \mathrm{mol}$ in HyClone WTF, corresponding to a phosphorous-silicon interaction mechanism. Phosphorous species favored corrosion and contributed to enhanced Si dissolution, while chlorides were not so influential, and applied anodic potential induced pseudo-passivation. These results highlight the importance geometrical configurations can have on a material's surface stability.

(C) The Author(s) 2019. Published by ECS. This is an open access article distributed under the terms of the Creative Commons Attribution 4.0 License (CC BY, http://creativecommons.org/licenses/by/4.0/), which permits unrestricted reuse of the work in any medium, provided the original work is properly cited. [DOI: $10.1149 / 2.0241906 \mathrm{jes}]$

(cc) BY
\end{abstract}

Manuscript submitted December 4, 2018; revised manuscript received March 5, 2019. Published March 20, 2019.

Silicon ( $\mathrm{Si}$ ) is normally considered as bioinert and therefore envisaged in a series of new applications. For example, Si based microelectronic devices provide new opportunities for the fabrication of neuroprosthetics such as cochlear, retina and spinal implants, for treating neurological deficits. ${ }^{1,2}$ Further, due to its good adhesive properties, Si can be used as an interlayer material in coated orthopedic implants such as hip and knee replacements. ${ }^{3,4}$ As with most implantable devices however, problems arise when trying to simulate the long-term in-vivo environment during in-vitro testing. There are hence reported instances of Si-based implants corroding in the body or in animal hosts, despite successful in-vitro testing. ${ }^{5}$ For example, Diamond-like Carbon (DLC) coated $\mathrm{Ti}_{6} \mathrm{Al}_{4} \mathrm{~V}$ femoral heads, containing a $\mathrm{Si}$ adhesion promoting interlayer, were expected to increase the lifetime of hip implants. In reality, many failed after only a few years of implantation. ${ }^{6}$ Focused ion beam (FIB) cuts into the failed hip explants revealed that the $\mathrm{Si}$ adhesion promoting interlayer (original thickness of ca. $70-100 \mathrm{~nm}$ ) had almost completely dissolved at some areas, as shown in Fig. 1. This corrosion phenomenon resulted in severe local delamination of the coating. ${ }^{7,8}$ Similarly, a DLC coated CoCrMo toe joint containing a $\mathrm{Si}$ interlayer was explanted after 4 years in a patient, due to failure of the interlayer. ${ }^{9}$ Platinum $(\mathrm{Pt})$ coated Si microelectrode arrays, for neuroprosthetic applications, showed delamination of the $\mathrm{Pt}$ and signs of pitting corrosion on the underlying $\mathrm{Si}$ after 994 days in-vivo. ${ }^{10}$ Severe corrosion of Si retinal chips was observed after 6 months of implantation in a rabbit, even though no significant damage occurred during in-vitro testing with immersion in phosphate buffered saline (PBS) solution for up to 21 months. ${ }^{11}$ Similarly, large dissolution rates of up to $18 \mu \mathrm{m} /$ year (ca. $2 \mathrm{~nm} / \mathrm{h}$ ) were recorded on polished Si pieces after one year of implantation in an animal host. ${ }^{12}$ In some instances, protective coatings were used on Si substrates to suppress corrosion, but they turned out to be ineffective. For example, Si carbide $(\mathrm{SiC})$ and DLC coatings showed poor protection of the underlying $\mathrm{Si}$ in saline solutions. ${ }^{13}$ The in-vivo environment further promoted dissolution of Si oxide and Si nitride/oxynitride films, leaving the substrate exposed. ${ }^{14,15}$

From a thermodynamic perspective (Pourbaix diagram ${ }^{16}$ ), $\mathrm{Si}$ is stable in the acidic to weakly alkaline domain, due to the formation

*Electrochemical Society Member.

${ }^{\mathrm{z} E-m a i l: ~ e m i l i j a . i l i c @ e m p a . c h ~}$ of a protective $\mathrm{Si}$ dioxide $\left(\mathrm{SiO}_{2}\right)$ film, ca. $1 \mathrm{~nm}$ in thickness, on its surface. $\mathrm{Si}$ is mainly known to be unstable in very alkaline solutions (ca. $\mathrm{pH}>10$ ) due to complexation with hydroxides $\left(\mathrm{OH}^{-}\right)$, and in the presence of fluoride $\left(\mathrm{F}^{-}\right)$. For these reasons, in micromachining application, $\mathrm{Si}$ is mostly etched in strongly alkaline media or hydrofluoric acid-based solutions. In physiological solutions (ca. pH 7.4), Si is expected to passivate (formation of a nm-thick oxide layer), given the electrolyte/surface potential is kept in the stability regime of $\mathrm{SiO}_{2}$, approximately above $-0.8 \mathrm{~V}_{\mathrm{SHE}}$. These stability conditions are extrapolated from the standard $\mathrm{Si}-\mathrm{H}_{2} \mathrm{O}$ system at $25^{\circ} \mathrm{C}$ and do not account for the presence of specific body ions, proteins, and body temperature $\left(37^{\circ} \mathrm{C}\right)$

A key parameter often overlooked when assessing Si stability invitro, is the added geometrical constraints generated through in-vivo implantation. A Si component wedged between body tissues will behave differently than a wafer piece immersed in bulk physiological simulating solution, hence the two conditions cannot accurately be compared. In-vivo, a degradation induced local $\mathrm{pH}$ change may occur in areas confined by surrounding body tissue, as a result of pitting and crevice corrosion attack of the implanted material. A similar statement can be made for $\mathrm{Si}$ as an interlayer; the thin interlayer is confined between the coating and substrate, and miniature defects in the coating can allow surrounding body fluid to contact the interlayer, forming an electrochemical crevice cell. In addition, electrochemical galvanic coupling can occur between the substrate and interlayer. Hence, it is important to assess the susceptibility of Si to pitting and aggravated crevice corrosion, before real implantable devices are used in-vivo.

In the present study, a thorough investigation of the corrosion behavior of $\mathrm{Si}$ in crevices and confined geometrical environments is presented, using a model geometry and electrochemical cells to analyze the different key parameters (temperature, ionic species, $\mathrm{pH}$ evolution, applied potential, material conductivity/doping) controlling the degradation mechanisms. Initiation and dissolution kinetics have been assessed by a combination of long-term and temperature accelerated immersion tests in physiological simulating solutions, along with complementary electrochemical and $\mathrm{pH}$ measurements. The findings presented can provide insight into the degradation mechanisms responsible for the failure of $\mathrm{Si}$ in the body, whether as it relates to coating adhesion interlayers (as described in Fig. 1) or electronic sensors. With this, better predictions of the lifetime and durability of implantable components and Si-based interlayers can be made, and 


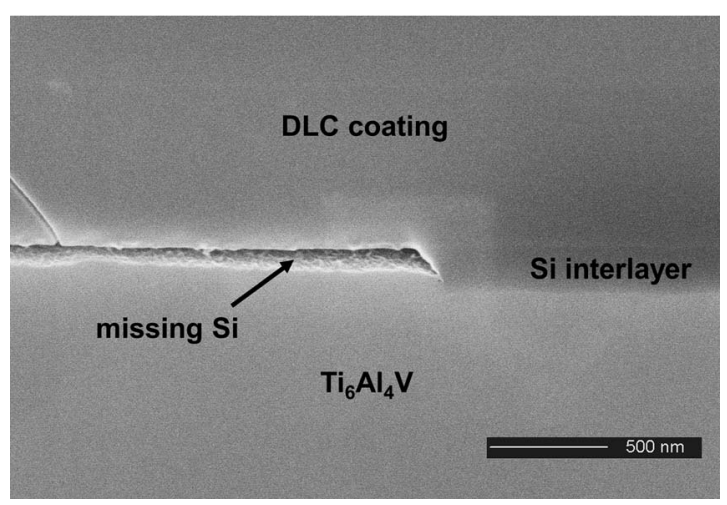

Figure 1. FIB cross section of an explanted DLC coated $\mathrm{Ti}_{6} \mathrm{Al}_{4} \mathrm{~V}$ hip joint ball. Crevice corrosion related attack appears where a Si interlayer has uniformly dissolved away (described further by Hauert et al. ${ }^{5,6}$ ).

the presented methodologies can as well be applied to any material surface degradation process.

\section{Experimental}

Samples and solutions.-Boron (B) doped polished Si (p-type, 1-30 $\Omega \cdot \mathrm{cm}$ ) wafer pieces with a thickness of ca. $0.5 \mathrm{~mm}$ and with a (100) crystal orientation, were cleaned by ultrasonic bath in ethanol and dried under argon flow. Corrosion experiments were performed in two different physiological simulating solutions: $0.01 \mathrm{M}$ phosphate buffered saline (PBS, Sigma Aldrich) of $\mathrm{pH} 7.4$, and HyClone Wear Testing Fluid (HyClone WTF, Thermo-Scientific) of pH 7.4-7.7. PBS has a relatively simple formulation, containing $0.137 \mathrm{M} \mathrm{NaCl}$, $0.0027 \mathrm{M} \mathrm{KCl}, 0.01 \mathrm{M} \mathrm{Na}_{2} \mathrm{HPO}_{4}$ and $0.0018 \mathrm{M} \mathrm{KH}_{2} \mathrm{PO}_{4}$. HyClone WTF is bovine serum-based and is designed to simulate human synovial fluid by containing all the relevant body ions (phosphate, chloride, etc.) and $30 \mathrm{~g} / \mathrm{L}$ of proteins.

Immersion experiments.—Long-term crevice and bulk solution immersion experiments were performed in 0.01 M PBS and HyClone WTF. Using a polyoxymethylene (POM) clamping device, two $\mathrm{Si}$ wafer pieces $(10 \times 10 \mathrm{~mm}$ and $20 \times 20 \mathrm{~mm}$ dimensions $)$ were clamped together (as sketched in Fig. 3a in the initial situation) to form a simple confined/crevice cell (denoted $\mathrm{Si} \mid \mathrm{Si}$ ) and immersed in $100 \mathrm{~mL}$ of $0.01 \mathrm{M}$ PBS or HyClone WTF. Throughout the paper, the term crevice will be used to describe the tight space between two clamped counterparts (maximum a few microns in thickness), while the term confinement will be used to describe a slightly larger separation (ca. $0.5 \mathrm{~mm}$ ), directly outside of the crevice or set by a spacer, as described in Fig. 3a. A droplet of the respective solution was placed between the wafer pieces before clamping to ensure the presence of electrolyte inside the crevice area. In order to compare the degradation mechanisms with the situation in bulk solution, single $\mathrm{Si}$ wafer pieces were also immersed in $100 \mathrm{~mL}$ of each solution. After 35 days of immersion at room temperature $\left(20^{\circ} \mathrm{C}\right)$ or $37^{\circ} \mathrm{C}$, the samples were unclamped, ultrasonically cleaned in ultrapure water, and dried under argon for further ex-situ surface characterization.

Accelerated immersion experiments were also performed by elevating the temperature and reducing the immersion time accordingly. In $0.01 \mathrm{M}$ PBS, this was done at $50^{\circ} \mathrm{C}, 70^{\circ} \mathrm{C}$ and $90^{\circ} \mathrm{C}$, for $240 \mathrm{~h}$, $24 \mathrm{~h}$, and $5 \mathrm{~h}$, respectively. In HyClone WTF, the experiments were only performed until $50^{\circ} \mathrm{C}$ in order to avoid substantial protein denaturation.

Electrochemical experiments.-To obtain more detailed information about the $\mathrm{Si}$ destabilization mechanisms (initiation, active dissolution), in-situ characterization was implemented. Open circuit potential (OCP) and electrochemical polarization measurements (potentiodynamic and potentiostatic) were conducted on $\mathrm{Si}$ in bulk 0.01 M PBS and HyClone WTF, with a PGSTAT30 potentiostat (Metrohm-Autolab). A three electrodes electrochemical cell setup was used with an exposed Si working electrode (WE) area of $78 \mathrm{~mm}^{2}$ and an electrolyte volume of $100 \mathrm{~mL}$. A glass Luggin capillary was used as an electrolyte bridge with a $3 \mathrm{M}$ silver/silver chloride $(\mathrm{Ag} / \mathrm{AgCl})$ reference electrode (RE, Metrohm). For the electrochemical polarization experiments, a platinum counter electrode (CE, Metrohm) was included and a scan rate of $1 \mathrm{mV} / \mathrm{s}$ was applied.

For electrochemical characterization in small electrolyte volumes, a modification of the confined/crevice cell was designed to monitor the OCP of the Si surface at different locations in the confined area, as described in Fig. 2a. Two epoxy blocks with 4 POM screws were used as a clamping device and a $20 \times 20 \mathrm{~mm} \mathrm{Si} \mathrm{piece,} \mathrm{acting} \mathrm{as} \mathrm{a} \mathrm{WE,} \mathrm{was} \mathrm{con-}$ tacted with a copper wire and imbedded into the bottom epoxy block. A $0.5 \mathrm{~mm}$ thick polypropylene $(\mathrm{PP})$ spacer with a $10 \times 15 \mathrm{~mm}$ central cut-out area was placed between the epoxy blocks before clamping, so that a small amount of electrolyte could access the confined area. A $3 \mathrm{M} \mathrm{Ag} / \mathrm{AgCl} \mathrm{RE}$ with an attached salt bridge (a plastic pipette tip filled with agar infused with $1 \mathrm{M} \mathrm{NaCl}$ ) was inserted through a small hole $(\varnothing=1 \mathrm{~mm})$ in the top block. A second RE-salt bridge assembly was placed outside of the cell at the confinement opening. With this RE configuration, the OCP could be monitored simultaneously inside and outside of the confined cell, using a multichannel zero-resistance ammeter (ZRA GalvoGill 12, ACM Instruments). The cell with electrodes was immersed in $100 \mathrm{~mL}$ of $0.01 \mathrm{M}$ PBS or HyClone WTF, contained within a double-walled glass vessel so that the temperature could be controlled.

Separate measurements were performed at $50^{\circ} \mathrm{C}$, followed by $70^{\circ} \mathrm{C}$ in $0.01 \mathrm{M} \mathrm{PBS}$, and at $37^{\circ} \mathrm{C}$, followed by $50^{\circ} \mathrm{C}$ in HyClone WTF, for $48 \mathrm{~h}$ at each temperature. The $\mathrm{Si}$ working electrodes were ground with 1000 Grit CarbiMet paper prior to cleaning in order to establish good electrical contact.

In order to determine the $\mathrm{pH}$ inside of the confined/crevice cell configuration, the clamping device was slightly modified; a hole was drilled in the opposing epoxy clamp and filled with agar gel infiltrated with a $\mathrm{pH}$ indicator, as seen in Fig. 2b. Duplicate immersion experiments were performed with different $\mathrm{pH}$ indicators; one with phenolphthalein which turns pink above $\mathrm{pH} 8.5$, and the other with thymolphthalein which turns blue above $\mathrm{pH} 10$

Post immersion characterization.-After immersion and cleaning treatment, the surfaces of the Si samples were inspected with a scanning electron microscope (SEM, Hitachi S-3700N). In order to quantify the magnitude of corrosive attack, surface profiles were taken over the wafer pieces with a DektakXT stylus profiler (Bruker). The corroded vertical depth was determined by performing several line scans over each sample's surface, measuring the height of the step $(\Delta h)$ at the crevice/confinement boundary and taking an average value, denoted $\Delta \mathrm{h}_{\text {corr }}$. The corrosion rate could be determined by dividing $\Delta \mathrm{h}_{\text {corr }}$ by the immersion time.

\section{Results and Discussion}

Long-term immersion experiments in physiological simulating conditions.-The results of the long-term confined/crevice and bulk solution immersion experiments at $37^{\circ} \mathrm{C}$ exposure in physiological simulating solution are presented before different stress parameters (temperature, ionic concentration) are varied to establish a model for the active corrosion mechanism.

A schematic description of the initial (upon immersion) and resulting (after 35 days) situation of a Si | Si confined/crevice cell immersed in HyClone WTF at $37^{\circ} \mathrm{C}$ is shown in Fig. 3a. After opening the crevice and cleaning the clamped counterparts, a SEM image was taken of the $20 \times 20 \mathrm{~mm}$ Si wafer piece over the area containing the crevice mouth (indicated by "0"), as shown in Fig. 3b. Two distinct regions can be seen in the SEM image; one with severe pitting in the crevice area on the left (indicated by "-" arrow), and another uniformly corroded 

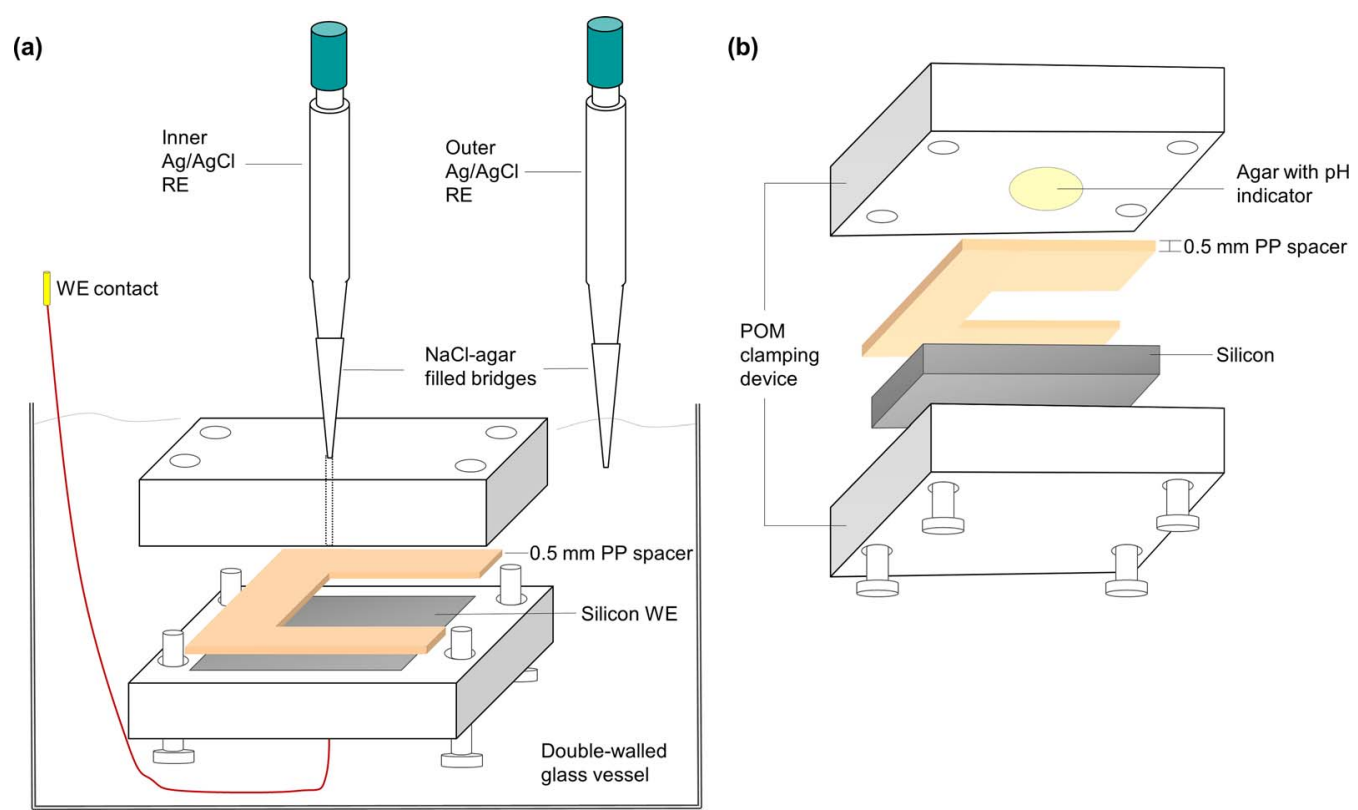

Figure 2. Schematic description of the confinement cell setup (referred as confined/crevice setup in the paper). (a) Used for conducting electrochemical measurements. (b) Modified cell used to determine $\mathrm{pH}$ evolution inside a crevice: agar is infiltrated with phenolphthalein (turns pink at $\mathrm{pH} 8.5-10$ ), or thymolphthalein (turns blue above $\mathrm{pH} 10) \mathrm{pH}$ indicator, and imbedded in the top clamp.

area in the confinement on the right (indicated by "+" arrow). The two regions are separated by a prominent vertical step at the crevice mouth (at location "0"), better evidenced in Fig. 4. The distinct pyramidal shape of the pits is characteristic of anisotropic (crystallographic orientation-dependent) attack of the faster dissolving (100) and (110) planes, leaving the more stable (111) planes intact. This orientationdependent dissolution behavior is known to occur in alkaline solutions, such as in $\mathrm{KOH}$ and $\mathrm{NaOH},{ }^{17}$ it is however usually not observed in media of $\mathrm{pH}$ 7.4-7.7. The topography after prolonged immersion has been characterized by $1 \mathrm{~mm}$ profilometer linescans across these two regions, one representative example is shown in Fig. 4. Indeed a very prominent vertical step can be seen at the crevice mouth where a maximum depth of ca. $3 \mu \mathrm{m}$ (corresponding to a dissolution rate of $3.6 \mathrm{~nm} / \mathrm{h}$ ) of Si has almost uniformly corroded away along the whole confined area. Throughout the paper, the corrosion rates in the confined area are calculated based on this maximum uniform dissolution height, $\Delta \mathrm{h}_{\text {corr }}$, measured at the prominent step. Considering the shape of the profile in Fig. 4, and that the most severe damage occurs di- rectly at the crevice mouth $(0 \mathrm{~mm})$, suggests that a galvanic coupling mechanism may be occurring between the electrochemical reactions directly outside in the confined space, balancing the localized corrosion attacks observed inside the crevice. The experiments of the next sections are designed to give more insight into this mechanism. In contrast to the confined/crevice cell immersion conditions, single wafer pieces immersed in bulk HyClone WTF for an equal duration did not show any detectable damage.

Considering 0.01 M PBS, the immersion experiment at $37^{\circ} \mathrm{C}$ for 35 days showed neither visual nor quantifiably detectable damage, both in the case of the confined/crevice and single wafer samples. Some corrosion was detected however after a much longer immersion time of 157 days in the confined/crevice setup, after which $\Delta \mathrm{h}_{\text {corr }}$ was measured to be $170 \mathrm{~nm}$.

HyClone WTF is much more complex in composition than $0.01 \mathrm{M}$ PBS and it is therefore difficult to identify exactly which components are contributing to its harsher influence on Si corrosion. One first hypothesis could be that the protein-containing solution is much more
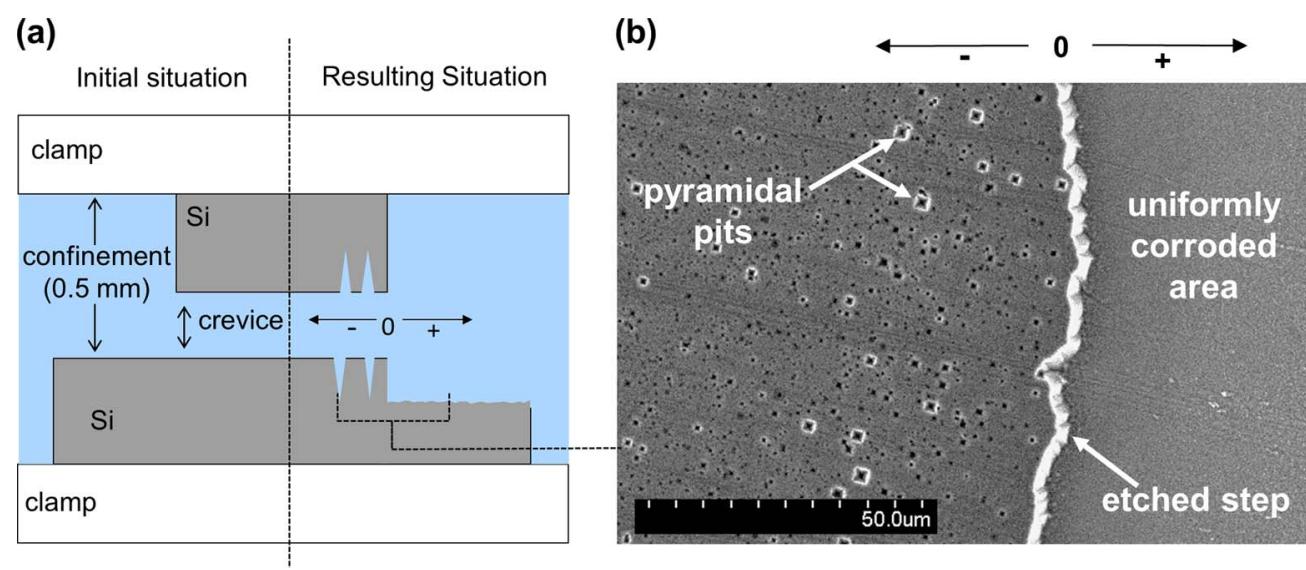

Figure 3. (a) Schematic description (exaggerated for clarification) of the corrosion processes occurring in a Si $\mid \mathrm{Si}$ confined/crevice configuration showing the initial immersion situation, and the resulting situation after 35 days; at the crevice mouth (indicated by "0") a uniformly corroded area occurs to the right in the confinement ("+" arrow), while pits are found to the left inside the crevice ("-" arrow). (b) Resulting SEM image of the bottom Si wafer close to the vicinity of the crevice mouth; unclamped after 35 days in a HyClone WTF containing crevice at $37^{\circ} \mathrm{C}$. Pyramidal pits are present in the crevice area, and a distinct step occurs at the crevice mouth where the smaller opposing Si piece was clamped. 


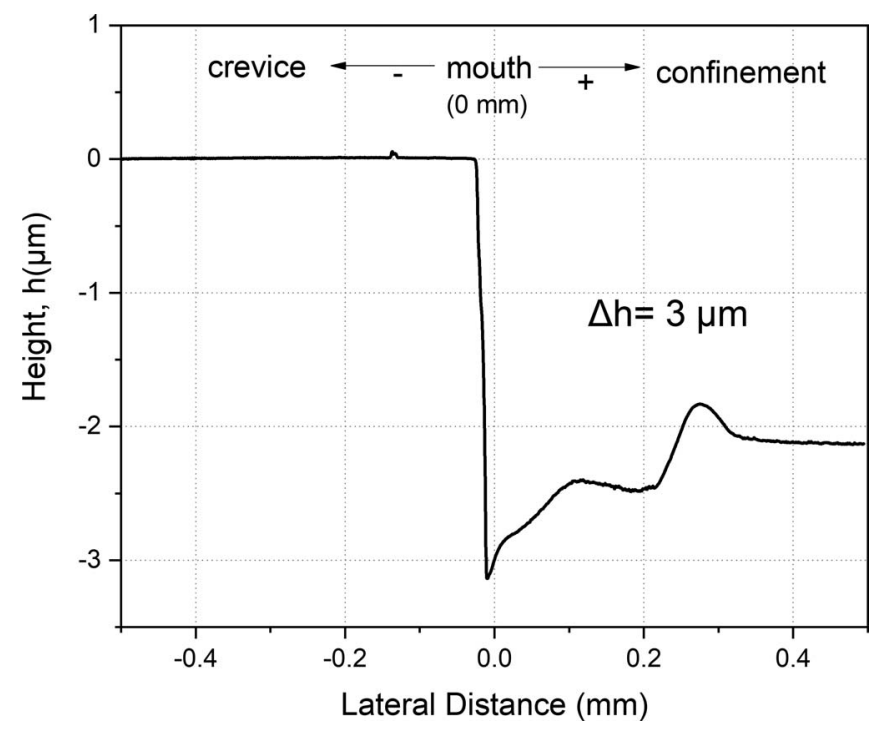

Figure 4. A profilometer topography scan corresponding to Fig. $3 b$ shows a significant corroded depth with a maximum of ca. $3 \mu \mathrm{m}$ at the mouth (indicated at $0 \mathrm{~mm}$ ) of the $\mathrm{Si} \mid \mathrm{Si}$ confined/crevice area, after 35 days immersion in HyClone WTF at $37^{\circ} \mathrm{C}$.

viscous and hence slows down ionic exchange and diffusion throughout the electrochemical cell.

Accelerated immersion experiments in confined/crevice conditions.-Following the corrosion investigation and processes observed at $37^{\circ} \mathrm{C}$, temperature was used as a kinetic acceleration factor to investigate the passive oxide stability threshold and corrosion rates. The resulting corrosion rates of the accelerated $\mathrm{Si} \mid \mathrm{Si}$ confined/crevice immersion experiments at elevated temperatures of $50-90^{\circ} \mathrm{C}$ are presented in an Arrhenius plot (ln[corrosion rate] versus 1/T) in Fig. 5, along with the corrosion rates obtained at $20^{\circ} \mathrm{C}$ and $37^{\circ} \mathrm{C}$. In $0.01 \mathrm{M}$ PBS, the corrosion rates range from $5.4-416.7 \mathrm{~nm} / \mathrm{h}$ for temperatures between $50-90^{\circ} \mathrm{C}$, while in HyClone WTF, measurable corrosion is already initiated at $20^{\circ} \mathrm{C}$ with corrosion rates of $0.4-13.8 \mathrm{~nm} / \mathrm{h}$. The dissolution mechanisms in both solutions yield a linear trend in the Arrhenius plot, suggesting that a single rate-limiting process is occur-

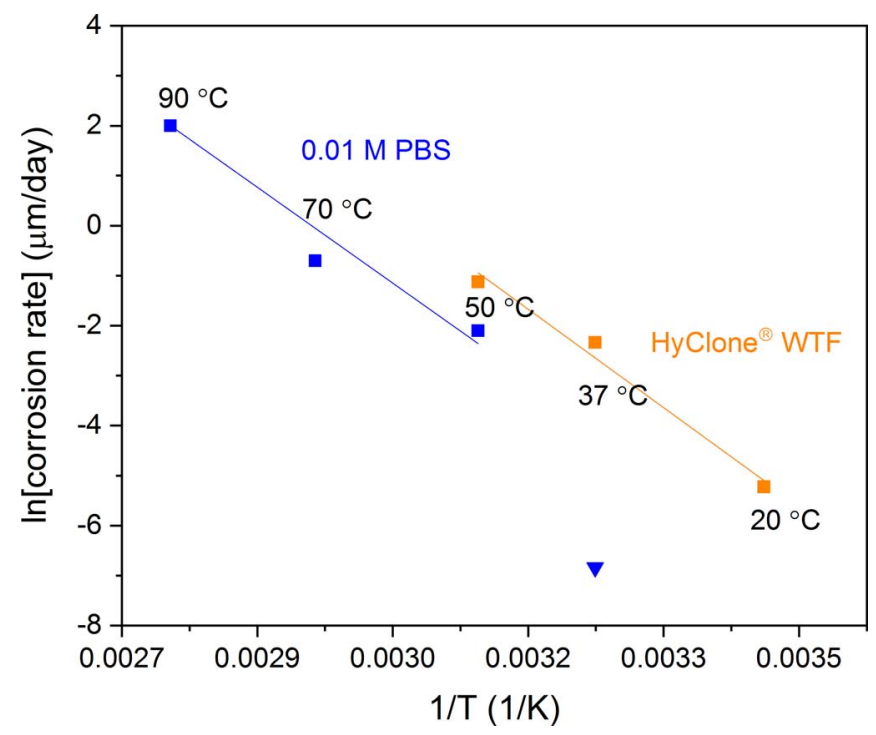

Figure 5. Arrhenius plot demonstrating a linear active Si dissolution mechanism in 0.01 M PBS and HyClone WTF measured in the confined area.

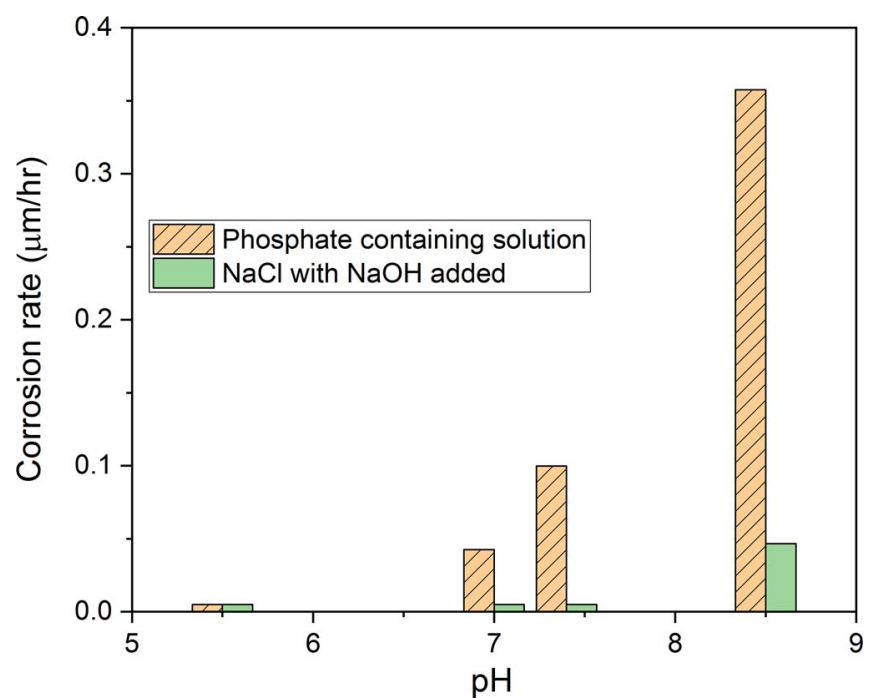

Figure 6. Corrosion rates of $\mathrm{Si}$ at the confined area when immersed in $\mathrm{NaCl}$ and phosphate-containing crevices $\left(\mathrm{K}_{2} \mathrm{HPO}_{4}, \mathrm{Na}_{2} \mathrm{HPO}_{4}, \mathrm{PBS}\right)$ at $90^{\circ} \mathrm{C}$ for $2 \mathrm{~h}$. For $\mathrm{NaCl}$ solutions, $\mathrm{pH}$ was initially adjusted by $\mathrm{NaOH}$ addition.

ring, and that temperature does not alter the dissolution mechanism but only its rate. It has to be mentioned that the corrosion rates are determined assuming immediate corrosion initiation upon immersion and a constant dissolution rate throughout the whole immersion time. This approximation is certainly valid for higher temperature, whereas in the transition temperature range where passivation is still effective, initiation time and mechanisms need to be investigated with more sensitive methods. The immersion experiment performed in 0.01 M PBS at $37^{\circ} \mathrm{C}$ is a good example supporting the previous statement; the corrosion rate at $37^{\circ} \mathrm{C}$ was calculated considering a very long immersion duration of 157 days, but active corrosion was likely initiated later, long after the start of immersion. The delayed corrosion initiation explains why the measurement point falls off the Arrhenius trendline. It is a good example of how an in-vitro test performed for a shorter duration may provide misleading predictions of an implant's lifetime, given that the immersion experiment performed for 35 days showed no damage. Therefore, it would be incorrect to guarantee product stability at $37^{\circ} \mathrm{C}$, since crevice corrosion can sometimes take many months, or even years, to initiate. When considering the corrosion process for a passivating material like $\mathrm{Si}$, the initiation mechanism is key to understanding its corrosive failure. In the active corrosion domain, the obtained trendlines in Fig. 5 present nearly identical activation energies $\left(\mathrm{E}_{\mathrm{a}}\right), 106 \mathrm{KJ} / \mathrm{mol}$ in $0.01 \mathrm{M} \mathrm{PBS}$ and $109 \mathrm{KJ} / \mathrm{mol}$ in HyClone WTF. The $\mathrm{E}_{\mathrm{a}}$ for the dissolution of (100) oriented $\mathrm{Si}$ and $\mathrm{SiO}_{2}$ varies greatly depending on the ionic species present in the solution. In alkaline solutions, the $\mathrm{E}_{\mathrm{a}}$ for $\mathrm{Si}$ etching can vary between $38-63 \mathrm{KJ} / \mathrm{mol}$ and $77-87 \mathrm{KJ} / \mathrm{mol}$ for $\mathrm{SiO}_{2}$, depending on the solution concentration. ${ }^{18}$ Van Gelder found activation energies of $110 \mathrm{KJ} / \mathrm{mol}$ and $115 \mathrm{KJ} / \mathrm{mol}$, for $\mathrm{Si}$ and $\mathrm{SiO}_{2}$, respectively, etched in phosphorous acid $\left(\mathrm{H}_{3} \mathrm{PO}_{4}\right) .{ }^{19} \mathrm{It}$ was suggested that a soluble phosphorous-silicon complex may form, resulting in dissolution of the $\mathrm{Si}$ oxide and the substrate. Considering the similar activation energies obtained in this study, the phosphorous species present in PBS and HyClone WTF may contribute to similar phosphorous-silicon complex formation when confined in a small amount of stagnant liquid. To validate this hypothesis, additional experiments were performed to assess the influence that phosphates have on the degradation of $\mathrm{Si}$ and are presented in the next section.

Influence of phosphorous species.-While HyClone WTF contains proteins and phosphates but is complex in composition, $0.01 \mathrm{M}$ PBS is a relatively simple solution as it contains only potassium, sodium, chloride, and phosphate compounds. The influence each of these ionic species has on the dissolution of $\mathrm{Si}$ and its oxide could be 
Table I. Corrosion rates of $\mathrm{Si} \mid \mathrm{Si}$ confined/crevices in different solutions at $90^{\circ} \mathrm{C}$. (-) refers to no corrosion detected.

\begin{tabular}{|c|c|c|c|c|c|}
\hline Solution Nr. & Content & Concentration $(\mathrm{M})$ & $\% \mathrm{H}_{2} \mathrm{PO}_{4}{ }^{-} / \% \mathrm{HPO}_{4}{ }^{2-}$ & $\mathrm{pH}$ & Corrosion rate $(\mathrm{nm} / \mathrm{h})$ \\
\hline 1 & $\mathrm{KH}_{2} \mathrm{PO}_{4}$ & $\begin{array}{c}0.01 \\
0.1\end{array}$ & $99 / 1$ & 5 & - \\
\hline 2 & $\mathrm{NaH}_{2} \mathrm{PO}_{4}$ & $\begin{array}{c}0.01 \\
0.1\end{array}$ & $99 / 1$ & 5 & - \\
\hline 3 & PBS & 0.01 & $39 / 61$ & 7.4 & 19 \\
\hline 4 & $\mathrm{~K}_{2} \mathrm{HPO}_{4}$ & $\begin{array}{c}0.01 \\
0.1\end{array}$ & $5 / 95$ & 8.5 & $\begin{array}{c}358 \\
1182\end{array}$ \\
\hline 5 & $\mathrm{Na}_{2} \mathrm{HPO}_{4}$ & $\begin{array}{c}0.01 \\
0.1\end{array}$ & $5 / 95$ & 8.5 & $\begin{array}{l}105 \\
830\end{array}$ \\
\hline 6 & $\mathrm{NaCl}$ & $\begin{array}{c}0.01 \\
0.1\end{array}$ & $0 / 0$ & 5.5 & - \\
\hline
\end{tabular}

investigated by performing accelerated $\mathrm{Si} \mid \mathrm{Si}$ confined/crevice immersion experiments in solutions of various salts (Solutions 1-2, and 4-6, in Table I). The experiments were performed with two different solution concentrations $(0.01 \mathrm{M}$ and $0.1 \mathrm{M})$ for $2 \mathrm{~h}$ of immersion at $90^{\circ} \mathrm{C}$. The measured corrosion rates, determined by means of profilometer linescans $\left(\Delta \mathrm{h}_{\text {corr }}\right)$ are presented in Table I. Increasing the concentrations of the dibasic phosphate compounds $\left(\mathrm{K}_{2} \mathrm{HPO}_{4}\right.$ and $\left.\mathrm{Na}_{2} \mathrm{HPO}_{4}\right)$ in Solutions 4 and 5 drastically increased the $\mathrm{Si}$ corrosion rates. On the other hand, with the monobasic phosphate compounds $\left(\mathrm{KH}_{2} \mathrm{PO}_{4}\right.$ and $\mathrm{NaH}_{2} \mathrm{PO}_{4}$ ) of Solutions 1 and 2, no corrosion was detected $(-)$ regardless of concentration. The difference lies in the type of phosphate ion that predominates in each solution, which can be determined by a speciation analysis as a function of the $\mathrm{pH}^{20}$ The dihydrogen phosphate ion $\left(\mathrm{H}_{2} \mathrm{PO}_{4}{ }^{-}\right)$is weakly acidic and predominates in Solutions 1 and 2 , while the hydrogen phosphate ion $\left(\mathrm{HPO}_{4}{ }^{2-}\right)$ is weakly alkaline and predominates in Solutions 4 and 5 (see Table I). In 0.01 M PBS, at $\mathrm{pH} 7.4$, the amount of phosphate species are $39 \% \mathrm{H}_{2} \mathrm{PO}_{4}{ }^{-}$and $61 \%$ $\mathrm{HPO}_{4}{ }^{2-}$. Hence, it appears that the corrosion rate of $\mathrm{Si}$ is ultimately enhanced by increasing the alkaline $\mathrm{HPO}_{4}{ }^{2-}$ species in solution. In chloride-containing solution, corrosion was not detected or was much less drastic. Even when chloride-containing solutions were made alkaline by the addition of $\mathrm{NaOH}$, the $\mathrm{Si}$ corrosion rates were still much lower than in the phosphate-containing solutions of equal $\mathrm{pH}$, as seen in Fig. 6. These observations indicate that phosphorous-silicon complex formation is a key accelerating factor in the destabilization and corrosion initiation of passivated $\mathrm{Si}$ in neutral to slightly alkaline solutions. Si-hydroxide complex formation is then known to be responsible for the dissolution of $\mathrm{Si}$ in the more alkaline solutions. Little research has been published on the interaction between phosphate species and Si but given the results presented in this study, a soluble phosphoroussilicon complex as proposed by W. van Gelder, ${ }^{19}$ may indeed be the factor controlling oxide film destabilization and active $\mathrm{Si}$ dissolution.

Electrochemical characterization of Si passive film stability.To investigate the stability of $\mathrm{Si}$ oxide and how it relates to corrosion initiation, electrochemical characterization of the potential and current evolution as a function of the immersion conditions (solution, time, and temperature) was performed. Fig. 7 presents the potentiodynamic polarization measurement for $\mathrm{Si}$ immersed in bulk $0.01 \mathrm{M}$ PBS and HyClone WTF at $37^{\circ} \mathrm{C}$ and selected higher temperatures. The polarization measurements obtained for Si immersed in $0.01 \mathrm{M}$ $\mathrm{NaCl}(\mathrm{pH} 5)$ and $\mathrm{NaOH}(\mathrm{pH} 13)$ at $37^{\circ} \mathrm{C}$ are included to demonstrate the passive oxide stability boundary domain; from very protective at $\mathrm{pH} 5$ to active dissolution at $\mathrm{pH}$ 13. It can be seen that a kinetic reaction equilibria between oxygen reduction and Si oxidation in the very stable passive surface condition induces nobler (more positive) corrosion potentials $\left(\mathrm{E}_{\text {corr }}\right)$ and lower corrosion current densities $\left(\mathrm{i}_{\text {corr }}\right)$, for $\mathrm{Si}$ immersed in $\mathrm{NaCl}$ and $0.01 \mathrm{M} \mathrm{PBS}$ at $37^{\circ} \mathrm{C}$. With increasing $\mathrm{pH}$ or temperature, the passive Si-oxides in contact with HyClone WTF and 0.01 M PBS progressively become unstable, as evidenced by a negatively shifting $\mathrm{E}_{\text {corr }}$ and increasing $\mathrm{i}_{\text {corr }}$. Small active-passive transitions in the current curves also start to be observed upon polarization. In $\mathrm{NaOH}$, a very active $\mathrm{E}_{\mathrm{corr}}$ of ca. $-1.2 \mathrm{~V}_{\mathrm{Ag} / \mathrm{AgCl}}$ indicates complete destabilization of Si-oxide in this media with active dissolution, as expected from the absence of thermodynamically stable phases (Pourbaix diagram ${ }^{16}$ ). Anodic potentiodynamic polarization however evidences that $\mathrm{Si}$, even in very alkaline $\mathrm{pH} 13$ solution, does not show very high active dissolution current densities. The maximum current density of ca. $10^{-4} \mathrm{~A} / \mathrm{cm}^{2}$ can be explained by hindered active dissolution related to the formation of poorly soluble $\mathrm{Si}$-complexes (oxi-hydroxides) on the Si surface. Formation of these intermediate products can explain why the $\mathrm{Si}$ surface does not remain active and re-passivates when polarizing away from the $\mathrm{E}_{\text {corr }}$. This very subtle difference in the surface oxide film stability is demonstrated by the presence of a plateau in the curve upon anodic polarization in $\mathrm{pH} 13$ but with a quite high current density $\left(>10^{-5} \mathrm{~A} / \mathrm{cm}^{2}\right)$, indicating the defective nature of the formed film (referred to as pseudo-passivation).

To better evidence this critical transition from soluble Si-complex formation inducing a decrease in active dissolution, to pseudo-passive oxide formation on the Si surface upon small anodic polarization, potentiostatic polarization experiments were performed in the $\mathrm{pH} 13$ solution around the polarization potentials where the active-passive current transition domain is observed. Indeed, very different current evolution behaviors are recorded when varying the applied potential between $-1 \mathrm{~V}_{\mathrm{Ag} / \mathrm{AgCl}}$ and $-0.8 \mathrm{~V}_{\mathrm{Ag} / \mathrm{AgCl}}$, as seen by the measurements presented in Fig. 8. The oxide stabilizes with a steady current decrease when the potential is held at $-0.8 \mathrm{~V}$, whereas it stays activated (constant higher current) at lower potentials closer to the corrosion potential, $E_{\text {corr }}$. These observations point to a surface oxide which is very sensitive to its chemical environment and is easily stabilized by anodic polarization. For this reason, monitoring the evolution of the

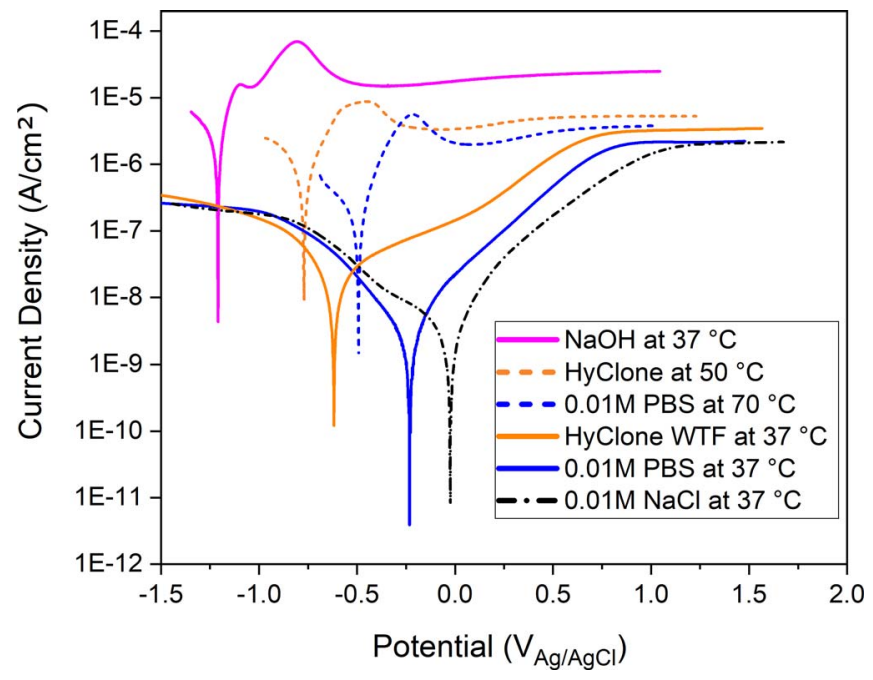

Figure 7. Anodic polarization measurements of $\mathrm{Si}$ at different temperatures in bulk solutions: $0.01 \mathrm{M} \mathrm{NaCl}(\mathrm{pH}$ 5), $0.01 \mathrm{M} \mathrm{PBS}$ (pH 7.4), HyClone WTF (pH 7.4-7.7), and $\mathrm{NaOH}(\mathrm{pH} 13)$. 


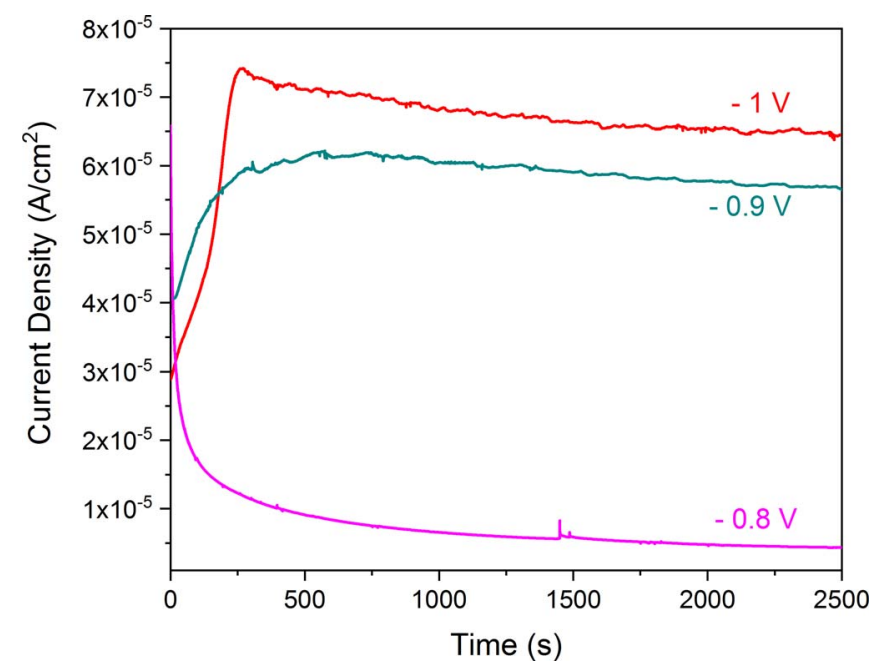

Figure 8. Potentiostatic polarization measurements of $\mathrm{Si}$ in bulk $\mathrm{NaOH}$, $\mathrm{pH} 13$, demonstrating the influence of applied potential on the passivation behavior.

free corrosion potential (OCP) provides a better diagnostic for the surface oxide stability and corrosion initiation susceptibility assessment. Large variations in the measured OCP can be expected depending on the degree of surface stability, from low values (ca. $-1.2 \mathrm{~V}_{\mathrm{Ag} / \mathrm{AgCl}}$ in

(a)

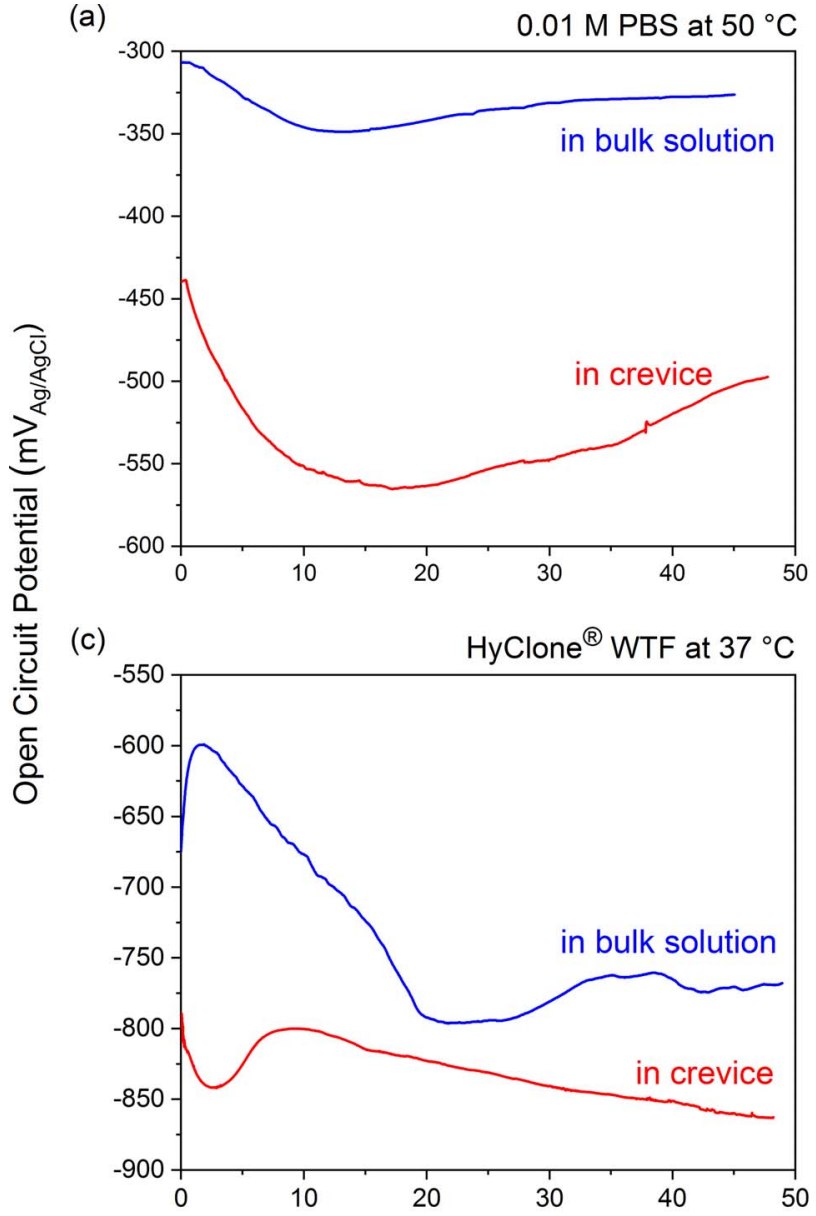

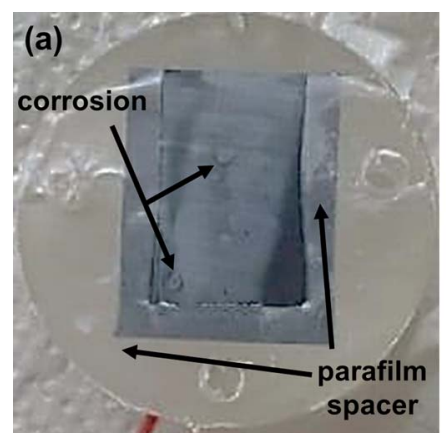

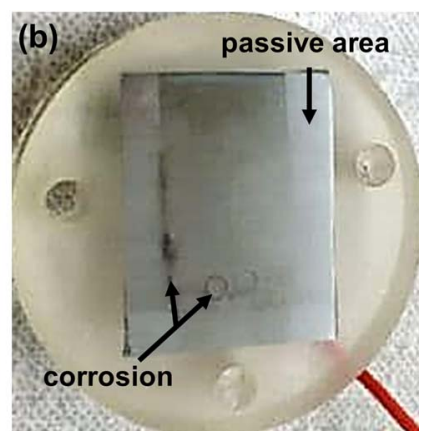

Figure 10. Optical images of $\mathrm{Si}$ surfaces after immersion in confined/crevice cells at $\mathrm{E}_{\text {corr }}$ in: (a) $0.01 \mathrm{M} \mathrm{PBS}$ at $50^{\circ} \mathrm{C}$ for $48 \mathrm{~h}$, then at $70^{\circ} \mathrm{C}$ for $48 \mathrm{~h}$, and (b) HyClone WTF at $37^{\circ} \mathrm{C}$ for $48 \mathrm{~h}$, then at $50^{\circ} \mathrm{C}$ for $48 \mathrm{~h}$.

the active state) to high potentials related to the presence of a stable Si-oxide, as identified by the electrochemical polarizations.

Open circuit potential (OCP) measurements.-OCP measurements were conducted over $48 \mathrm{~h}$ on Si working electrodes immersed in bulk solution and in the confined/crevice cell (as described in Fig. 2a). The results are presented in Fig. 9. In the confined/crevice cell, the OCPs measured by the inner and outer RE were nearly identical in the absence of an external cathode, and also related to the very small currents flowing without significant ohmic drops in the system. Hence,

(b)

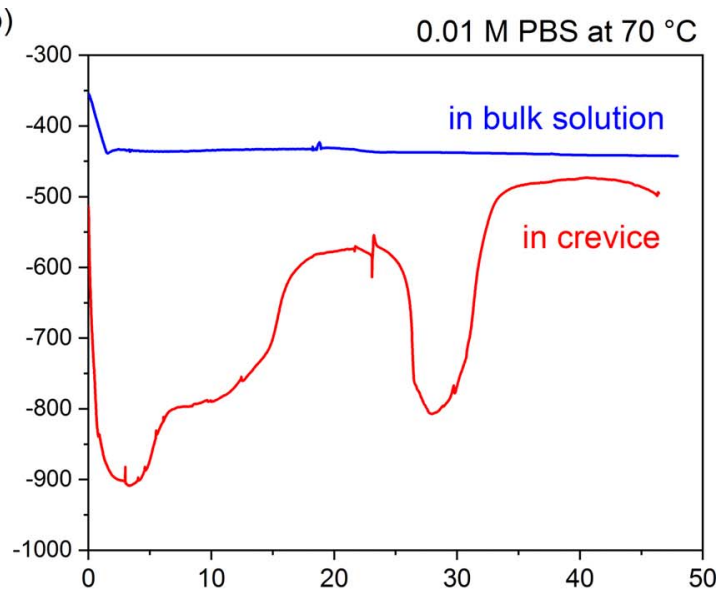

(d)

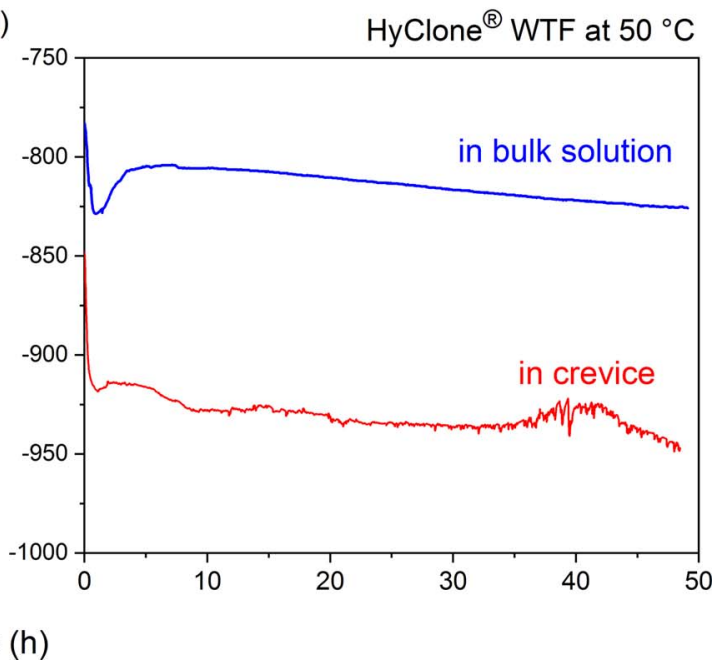

Figure 9. Open circuit potential (OCP) measurements of Si over $48 \mathrm{~h}$ in bulk solution and in the confined/crevice cell configuration: (a) $0.01 \mathrm{M}$ PBS at $50^{\circ} \mathrm{C}$, (b) $0.01 \mathrm{M} \mathrm{PBS}$ at $70^{\circ} \mathrm{C}$, (c) $\mathrm{HyClone} \mathrm{WTF}$ at $37^{\circ} \mathrm{C}$ and (d) $\mathrm{HyClone} \mathrm{WTF}$ at $50^{\circ} \mathrm{C}$. 


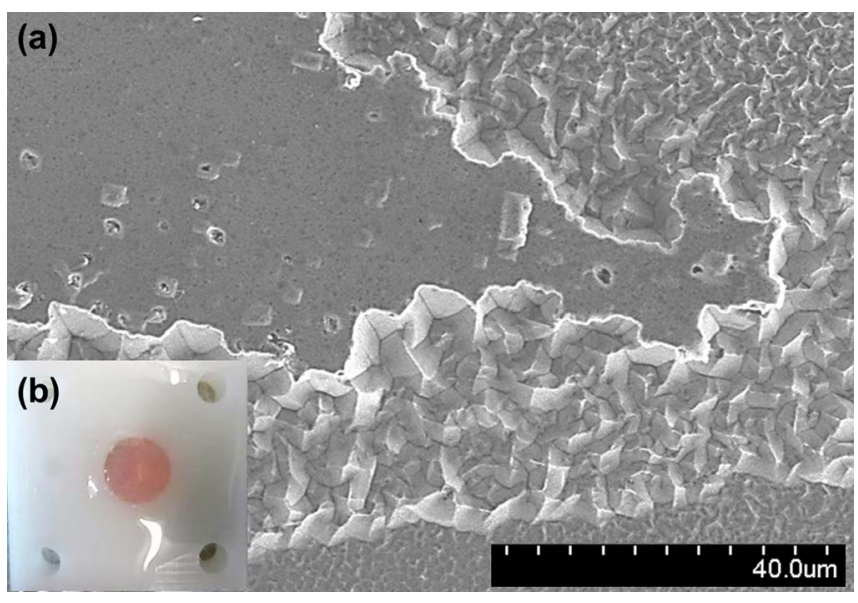

Figure 11. (a) Si after immersion in HyClone WTF ( $\mathrm{pH}$ 7.4-7.7) for 10 days at $50^{\circ} \mathrm{C}$, using the confined configuration from Fig. $2 \mathrm{~b}$. Area close to the confinement mouth is shown. (b) Agar infiltrated with phenolthalein turned pink, indicating a $\mathrm{pH}$ above 8.5 occurred.

only the OCP evolution at the inner position in the confined area is shown. It can be seen that the OCPs established in the confined area are much more active than the ones measured in bulk solution. This is most evident for samples immersed in $0.01 \mathrm{M} \mathrm{PBS}$ at $70^{\circ} \mathrm{C}$ (Fig. 9b), where the bulk OCP is at a constant noble value for Si of ca. $-430 \mathrm{mV}_{\mathrm{Ag} / \mathrm{AgCl}}$, but the OCP in the confined/crevice cell varies largely between $-500 \mathrm{mV}_{\mathrm{Ag} / \mathrm{AgCl}}$ and $-900 \mathrm{mV}_{\mathrm{Ag} / \mathrm{AgCl}}$. It is important to recall that the $\mathrm{Si} / \mathrm{SiO}_{2}$ equilibrium potential is ca. $-1000 \mathrm{mV}_{\mathrm{Ag} / \mathrm{AgCl}}$ at $\mathrm{pH} 7.4$ (in the $\mathrm{Si}-\mathrm{H}_{2} \mathrm{O}$ thermodynamic system). The large potential variation indicates an unstable surface oxide with active corrosion driving the OCP to low values $\left(-900 \mathrm{mV}_{\mathrm{Ag} / \mathrm{AgCl}}\right.$ ), and resulting corrosion products (as seen in Fig. 10a) providing some temporary protection of the Si surface, shortly bringing the OCP back up. This OCP fluctuation also shows that the potential decrease cannot be interpreted in terms of oxygen concentration decrease within the confinement, as this would induce a progressive OCP decay for all the experiments. The OCPs measured in HyClone WTF were more active than the ones measured in 0.01 M PBS. Even in bulk HyClone WTF solution, the OCP was fairly active with ca. -600 to $-750 \mathrm{mV} \mathrm{Ag} / \mathrm{AgCl}$ values at $37^{\circ} \mathrm{C}$ and ca. $-800 \mathrm{mV}_{\mathrm{Ag} / \mathrm{AgCl}}$ at $50^{\circ} \mathrm{C}$. The most active OCPs were observed for $\mathrm{Si}$ exposed to HyClone WTF in confined/crevice conditions, with values

\begin{tabular}{|c|c|c|c|}
\hline $\begin{array}{l}\text { Si wafer } \\
\text { batch }\end{array}$ & $\begin{array}{l}\text { Resistivity } \\
(\Omega \cdot \mathrm{cm})\end{array}$ & $\begin{array}{l}\text { B concentration } \\
\text { order }\left(\text { atoms } / \mathrm{cm}^{3}\right)\end{array}$ & $\begin{array}{l}\text { Corrosion } \\
\text { rate }(\mathrm{nm} / \mathrm{h})\end{array}$ \\
\hline 1 & 0.01 & $10^{19}$ & 0.04 \\
\hline 2 & $<0.1$ & $>3 \times 10^{17}$ & 0.05 \\
\hline 3 & 0.2 & $10^{17}$ & 0.09 \\
\hline 4 & $3-4.2$ & $10^{15}$ & 5.60 \\
\hline 5 & $3-5$ & $10^{15}$ & 2.41 \\
\hline 6 & $5-10$ & $10^{15}$ & 2.71 \\
\hline 7 & $6-7$ & $10^{15}$ & 0.41 \\
\hline
\end{tabular}

as low as ca. $-950 \mathrm{mV}_{\mathrm{Ag} / \mathrm{AgCl}}$ at $50^{\circ} \mathrm{C}$. Such low potential values point to a very corrosive system generated by the HyClone WTF, and indeed severe damages were observed when the cell was opened at the end of the experiment, as seen in Fig. $10 \mathrm{~b}$.

Influence of $S i$ wafer doping and resistivity on corrosion.When performing the $\mathrm{Si} \mid \mathrm{Si}$ confined/crevice immersion experiments, it was observed that the Si wafer resistivity (dependent on B-doping concentration $^{21}$ ) directly influenced its corrosion rate. All the experiments presented before were performed with $\mathrm{Si}$ wafers having intermediate resistance (Batch 4 in Table II). In order to investigate this dependency, the uniform corrosion rates in the confined/crevice setup geometry were compared for several wafer batches of varying resistivity. The experiments were performed with $\mathrm{Si} \mid \mathrm{Si}$ confined/crevices immersed in $0.01 \mathrm{M} \mathrm{PBS}$ at $50^{\circ} \mathrm{C}$ for 20 days. As seen in Table II, the wafers with the lowest resistivity (wafer Batches 1-3), i.e. highest B-doping, showed much lower corrosion rates than those of moderate resistivity (wafer Batches 4-7) with a maximum corrosion rate obtained for Batch 4. This may seem surprising, as an increase in $\mathrm{Si}$ conductivity would be expected to increase the corrosion rate, due to the greater availability of electrons for oxidation reactions. A direct correlation between increasing Si conductivity and increasing corrosion rate is indeed obtained when hydrofluoric-based isotropic (very active and uniform dissolution in all orientations) etchants are used; the etching rate increasing at a $B$ concentration above $10^{18}$ atoms $/ \mathrm{cm}^{3} .22$ However, the opposite phenomenon, as in our case, has been documented in alkaline anisotropic etchants such as $\mathrm{NaOH}$ and $\mathrm{KOH}$. When etching in anisotropic etchants, the $\mathrm{Si}$ etching rate greatly reduces in heavily B-doped wafers, commonly referred to as a p+ etch
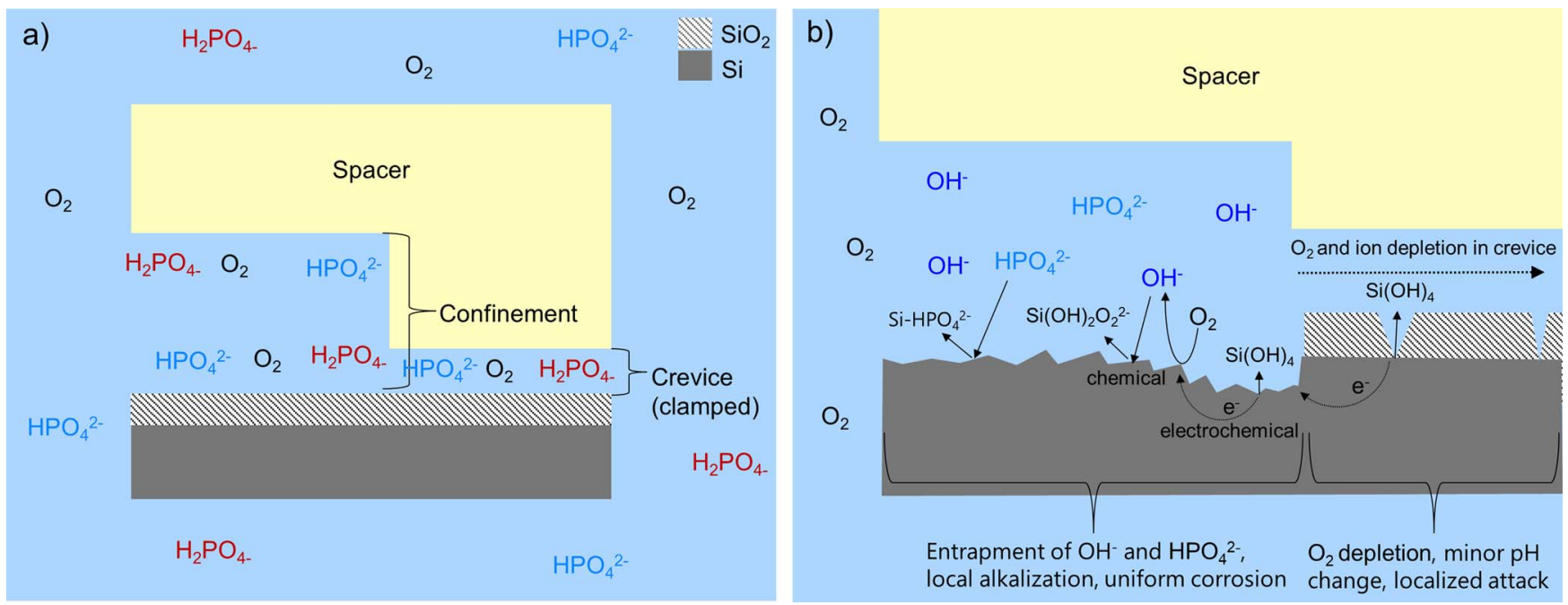

Figure 12. Schematic description of reaction mechanisms showing the influence of a confined/crevice geometry on the dissolution of Si in physiological solutions. a) Initial chemistry at the beginning of the immersion experiment. b) Corrosion mechanisms in the confined/crevice areas at longer immersion times, the areas of interest are enlarged for clarification. 
stop. ${ }^{18,22}$ Some authors found this etch stop B concentration to be on the order of $10^{19}$ atoms $/ \mathrm{cm}^{3}$ (ca. $\left.0.01 \Omega \cdot \mathrm{cm}\right),{ }^{18,23}$ while others reported it to be on the order of $10^{18}$ atoms $/ \mathrm{cm}^{3}$ (ca. $0.04 \Omega \cdot \mathrm{cm}$ ) in dilute $\mathrm{KOH}$ solutions. ${ }^{24}$ Hence, the findings presented in Table II can be considered consistent with literature. In the confined/crevice geometry, the situation is however slightly different. The higher Si wafer resistivity might explain the trenching (see Fig. 4) observed and the larger corrosion rate measured directly at the border between the crevice and confined area, due to localization of the cathodic reaction (controlling the anodic pitting in the crevice) at the crevice mouth.

pH determination in the confined cell.-In order to confirm that a cathodic-reaction-induced alkaline-type corrosion mechanism could be occurring inside the confined $\mathrm{Si}$ area, immersion experiments were performed using the $\mathrm{pH}$-determining device described in Fig. 2b. The device was opened after immersion in HyClone WTF for 10 days at $50^{\circ} \mathrm{C}$; the Si surface showed severe anisotropic attack within the area set by the spacer, as seen in Fig. 11a, and the agar infiltrated with phenolthalein was light pink in color, as seen in Fig. 11b. When thymolphthalein was used as the $\mathrm{pH}$ indicator, severe attack of the Si surface was also seen, but no color change of the agar was observed. This means that the $\mathrm{pH}$ increased and established between 8.5 and 10 within the confined space set by the spacer. The experiments performed in 0.01 M PBS at the same temperature and duration also showed substantial anisotropic attack of the $\mathrm{Si}$, but no color change was observed in the agar. While a surface $\mathrm{pH}$ increase on the corroding surface can certainly also occur in PBS, its buffering ability might prevent a measurable $\mathrm{pH}$ gradient in the agar.

Discussion of the corrosion mechanism.-Based on the results presented in this study and combining the different aspects of the degradation identified, a simple mechanism explaining the influence of a confined geometry and crevices on the dissolution of $\mathrm{Si}$ in physiological simulating solutions is presented in Fig. 12.

Initially, when the confined/crevice cell is immersed (or a defect in DLC coating is exposed to solution), a protective $\mathrm{SiO}_{2}$ film is present on the Si surface. This initial protection can be evidenced by a relatively noble measured $\mathrm{E}_{\text {corr }}$ value of ca. $-400 \mathrm{mV}_{\mathrm{Ag} / \mathrm{AgCl}}$ in $0.01 \mathrm{MPBS}$ at $37^{\circ} \mathrm{C}$ (as shown in Fig. 7), corresponding to the kinetic equilibrium between passive $\mathrm{Si}$ oxidation and oxygen reduction. The native $\mathrm{SiO}_{2}$ is ca. $1 \mathrm{~nm}$ in thickness (as identified by XPS) and in the presence of water can slowly dissociate into soluble ionic species (Equation 1). This may be the initial stage of surface oxide destabilization. In addition, even though $\mathrm{SiO}_{2}$ is in principle an insulator, such a thin oxide can allow electron tunneling from the $\mathrm{Si}$ to the oxide surface and provide them for cathodic oxygen reduction (Equation 2), so that the following reactions are possible:

$$
\begin{gathered}
\mathrm{SiO}_{2}+\mathrm{H}_{2} \mathrm{O} \rightarrow \mathrm{HSiO}_{3}{ }^{-}+\mathrm{H}^{+} \\
\mathrm{O}_{2}+2 \mathrm{H}_{2} \mathrm{O}+4 e^{-} \rightarrow 4 \mathrm{OH}^{-} \\
\mathrm{Si}+4 \mathrm{OH}^{-} \rightarrow \mathrm{Si}(\mathrm{OH})_{4}+4 e^{-} \\
\mathrm{Si}+\mathrm{H}_{2} \mathrm{O}+2 \mathrm{OH}^{-} \rightarrow \mathrm{Si}(\mathrm{OH})_{2} \mathrm{O}_{2}{ }^{2-}+2 \mathrm{H}_{2}
\end{gathered}
$$

With time, the $\mathrm{O}_{2}$ in the tight crevice is used up relatively rapidly, while the confined space continues to be supplied by $\mathrm{O}_{2}$. Oxygen reduction therefore predominates in the confined area, resulting in the generation of alkaline $\mathrm{OH}^{-}$species. With the use of $\mathrm{pH}$ indicators, a local $\mathrm{pH}$ increase between $\mathrm{pH} 8.5-10$ could be identified in the confined area (as shown in Fig. 11). Cathodic reaction induced local $\mathrm{pH}$ increases at a Si-oxide/electrolyte interface could also occur in bulk solution, however these surface $\mathrm{pH}$ gradients are short lived, due to better ionic diffusion and equilibration. In a confined geometry, ion diffusion becomes restricted, and accumulation of $\mathrm{OH}^{-}$can eventually lead to an additional anodic electrochemical (Reaction 3), or chemical (Reaction 4), alkaline-type dissolution mechanism. ${ }^{25}$

Considering purely the chemical equilibria and electrochemical thermodynamic aspects of the $\mathrm{Si}-\mathrm{H}_{2} \mathrm{O}$ system at $25^{\circ} \mathrm{C}$ (Pourbaix $\left.\operatorname{diagram}^{16}\right)$, generation of soluble species and active dissolution in the confined area would be occurring starting at ca. $\mathrm{pH} 10$. According to the $\mathrm{pH}$ range identified experimentally with the $\mathrm{pH}$ indicators, $\mathrm{pH} 10$ is not reached in the confined area. The confined electrolyte chemistry might however get close to this $\mathrm{pH} 10$ stability boundary and the surface $\mathrm{pH}$ is anyway difficult to assess. Additionally, elevating the temperature narrows the $\mathrm{SiO}_{2}$ thermodynamic stability domain inducing corrosion below $\mathrm{pH} 10$, and the experiments showed clear evidences of slow active dissolution (trenching) especially in the presence of phosphates. Surface activation, identified by a measured OCP decrease down to $-850 \mathrm{mV}_{\mathrm{Ag} / \mathrm{AgCl}}$, occurs already at $37^{\circ} \mathrm{C}$ in HyClone WTF and is clearly detectable for PBS in confined/crevice conditions from a temperature of $50^{\circ} \mathrm{C}$. In addition, when the $\mathrm{OCP}$ in the confinement drops to active values of ca. $-800 \mathrm{mV}_{\mathrm{Ag} / \mathrm{AgCl}}$ and $-950 \mathrm{mV}_{\mathrm{Ag} / \mathrm{AgCl}}$ (Fig. 9), cathodic hydrogen reduction can also occur and progressively accelerate corrosion.

Considering the systematic study of the influence of specific anions, phosphates and chlorides (Table I and Fig. 6), it becomes clear that the presence of phosphate is an additional parameter to consider in surface oxide destabilization. For measurements performed at $\mathrm{pH}$ 8.5 , no uniform corrosion is detected in the confined area in presence of chloride, supporting the fact that the predicted $\mathrm{pH} 10$ oxide stability boundary is valid in absence of the additional phosphate surface interactions. On the other hand, severe corrosion is identified at $\mathrm{pH} 8.5$ in the presence of phosphate species (Table I). The Arrhenius plot in Fig. 5 pointed to an activation energy related to the formation of soluble phosphorous-silicon complexes, as proposed by W. van Gelder. ${ }^{19}$

Lastly, considering in more detail the topography profile of Fig. 4 in relation with the Si resistivity discussion, some assumption can be made about galvanic coupling in the confined/crevice aeration cell geometry. For the middle resistivity domain (Batch $4 \mathrm{Si}$-wafer: $3-4.2 \Omega \cdot \mathrm{cm})$, a clear trench with enhanced dissolution at the confined/crevice border is continuously observed. For a semiconducting substrate, if a cathodic reaction can take place to initially support the anodic localized dissolution in the crevice, its rate will be higher at the confined/crevice border. The cathodic reaction is related to the observed $\mathrm{pH}$ increase, and in the presence of phosphate will increase the corrosion susceptibility also in the confined area. Lowering the resistance of the $\mathrm{Si}$ will better distribute the cathodic reaction along the confined surface during the initial stage of localized corrosion in the crevice, and might delay the $\mathrm{pH}$ change and detrimental effect in the confined area. This may explain why very low corrosive attack is measured and no trenching is visible in the confined area for the highly conductive wafers. Very high Si resistance on the other hand will hinder galvanic coupling and as a consequence decrease the trenching depth.

One aggravating factor that has not yet been identified is the exact component of the HyClone WTF that has a negative influence on the passive film stability. HyClone WTF already induces increased surface reactivity at $37^{\circ} \mathrm{C}$ (low OCP, corrosion) in the absence of a confinement/crevice geometry, meaning that its viscosity and hindered ionic diffusion might not be the only detrimental factor contributing to the corrosion mechanism.

\section{Conclusions}

An investigation of the corrosion behavior of $\mathrm{Si}$ in physiological simulating solutions (0.01 M PBS and HyClone Wear Test Fluid, $\mathrm{pH}$ 7.4-7.7) was presented in this study. Long-term and accelerated immersion experiments were developed to investigate the influence of crevices, confined spaces, and bulk solutions on Si stability. Complementary electrochemical measurements were conducted in bulk and confined/crevice configurations to study Si corrosion initiation and oxide stability. The following can be concluded:

- The stability of Si and its naturally grown surface oxide varies drastically between bulk, confined, and crevice immersion conditions.

- In a tight crevice (few microns in thickness), localized corrosion with the formation of pyramidal pits in $0.01 \mathrm{M}$ PBS and HyClone WTF was observed. 
- When constricted to a confined (ca. $0.5 \mathrm{~mm}$ thick electrolyte)/crevice geometry, Si corroded uniformly up to ca. $3.6 \mathrm{~nm} / \mathrm{h}$ in HyClone WTF at $37^{\circ} \mathrm{C}$, while no measurable damage was observed after exposure in bulk solution.

- Activation (surface oxide destabilization) could be evidenced by in-situ OCP evolution measurements in a confined electrochemical cell geometry; potentials were consistently more active (as low as $-950 \mathrm{mV} \mathrm{Ag}_{\mathrm{Aggl}}$ ) compared to the values measured in bulk solution for the simulated physiological solutions considered.

- A higher $\mathrm{pH}$ of 8.5-10 was measured in the confined area after immersion in HyClone WTF for several days, indicating that an alkalization process had occurred on the Si surface.

- The corrosion in the confinement was further accelerated by increasing the temperature and a linear Arrhenius trend with activation energies of $106 \mathrm{KJ} / \mathrm{mol}$ in $0.01 \mathrm{M} \mathrm{PBS}$, and $109 \mathrm{KJ} / \mathrm{mol}$ in HyClone WTF, was observed, corresponding to a phosphorous-silicon interaction mechanism.

- Alkaline phosphate species contributed to accelerating the Si corrosion initiation and dissolution rates, whereas chlorides seemed to have little influence on the Si corrosion susceptibility.

- The overall corrosion mechanism is initiated by galvanic coupling, as observed by the separation of pitting in the crevice and trenching at the border with the confined area, $\mathrm{pH}$ increase and phosphorous-silicon complexation.

Overall, when determining the stability of biomedical implantable components, this study illustrates the importance of considering geometrical aspects for in-vitro testing procedures, aspects which can be inherent of the implant design or generated by contact with tissue in the in-vivo environment. These findings can be used to provide better predictions of the lifetime of implantable Si components and Si-based interlayers, as well the presented methodologies can be applied to any other material of interest.

\section{Acknowledgments}

The authors acknowledge the Swiss National Science Foundation (project number 200021_156085) for financially supporting this research. Thank you also to Kerstin Thorwarth, Thomas Suter, Markus Faller and Olga Guseva from Empa, as well as Anna Igual Munoz from EPFL, for their helpful discussions.

\section{ORCID}

Emilija Ilic (D) https://orcid.org/0000-0002-0220-1258

\section{References}

1. D. J. Edell, Neuroprosthetics: Theory and Practice, K. H. Horch and G. S. Dhillon, Editors, 2nd ed., p. 517, Utah (2014).

2. E. Fernandez and R. Normann, Introduction to Visual Prostheses, H. Kolb, E. Fernandez, and R. Nelson, Editors, p. 11, Salt Lake City (2016).

3. M. Azzi, P. Amirault, M. Paquette, J. E. Klemberg-Sapieha, and L. Martinu, Surf. Coatings Technol., 204, 3986 (2010).

4. R. Butter, M. Allen, L. Chandra, A. H. Lettington, and N. Rushton, Diam. Relat. Mater, 4, 857 (1995).

5. A. Vanhoestenberghe and N. Donaldson, J. Neural Eng., 10, 13 (2013).

6. G. Taeger, L. E. Podleska, B. Schmidt, M. Ziegler, and D. Nast-Kolb, Materwiss. Werksttech., 34, 1094 (2003).

7. R. Hauert, C. V. Falub, G. Thorwarth, K. Thorwarth, Ch. Affolter, M. Stiefel, L. E. Podleska, and G. Taeger, Acta Biomater., 8, 3170 (2012).

8. R. Hauert, K. Thorwarth, and G. Thorwarth, Surf. Coatings Technol., 233, 119 (2013).

9. R. Hauert, G. Thorwarth, U. Müller, M. Stiefel, C. V. Falub, K. Thorwarth, and T. J. Joyce, Diam. Relat. Mater., 25, 34 (2012).

10. J. C. Barrese, J. Aceros, J. P. Donoghue, R. Island, and R. Island, J Neural Eng., 13, 27 (2016)

11. H. Hämmerle, K. Kobuch, K. Kohler, W. Nisch, H. Sachs, and M. Stelzle, Biomaterials, 23, 797 (2002)

12. D. J. Edell, D. Drive, and E. Suite, in Materials Research Society Symposium Proceedings, vol. 773, p. N1.9.1 (2013).

13. J. Morales, J. Souriau, and G. Simon, ECS Trans., 69, 9 (2015).

14. J. M. Maloney, S. A. Lipka, and S. P. Baldwin, in Materials Research Society Symposium Proceedings, vol. 872, p. J14.3.1 (2005).

15. M. Fröhlich, M. Birkholz, K. E. Ehwald, P. Kulse, O. Fursenko, and J. Katzer, in IOP Conference Series: Materials Science and Engineering, vol. 41, p. 012022 (2012).

16. J. Van Muylder, J. Besson, W. Kunz, and M. Pourbaix, in Atlas of Electrochemical Equilibria in Aqueous Solutions, p. 459, NACE, Houston (1974).

17. O. Powell and H. B. Harrison, J. Micromechanics Microengineering, 11, 217 (2001).

18. H. Seidel, L. Csepregi, A. Heuberger, and H. Baumgärtel, J. Electrochem. Soc., 137, 3612 (1990).

19. W. van Gelder and V. E. Hauser, J. Electrochem. Soc., 114, 869 (1967).

20. P. Hinsinger, Plant Soil, 137, 173 (2001).

21. W. R. Thurber, R. L. Mattis, Y. M. Liu, and J. J. Filliben, Semiconductor measurement technology: The relationship between resistivity and dopant density for phosphorus and boron doped silicon., p. 42, Washington, (1981).

22. C. A. Zorman and M. Mehregany, in The MEMS handbook. MEMS: Design and fabrication, M. Gad-el-Hak, Editor, p. 1, Taylor \& Francis Group (2006).

23. A. Bogh, J. Electrochem. Soc., 118, 401 (1971).

24. J. B. Price, H. R. Huff, and R. R. Burgess, in Semiconductor Silicon, p. 339, The Electrochemical Society Softbound Symposium, Princton, N.J. (1973).

25. X. G. Zhang, Electrochemistry of silicon and its oxide, Kluwer Academic/Plenum Publishers, New York (2001). 